\title{
A Colonial Curiosity: the Maori Poroaki as Victorian Dramatic Monologue.
}

\author{
John O'Leary
}

One of the enjoyable things about doing Ph.D. research in literature is the fact that it gives the student the opportunity to get to know another period, another place or another writer very well. One sees, perhaps, how little human nature has changed - but one also realizes how greatly human culture, and its literary expression, have altered. This notion was reinforced for me recently when, as part of my Ph.D. research, I was sitting in the National Library in Wellington scanning colonial newspapers dating from the early 1860's. Unlike their modern counterparts, which mention literature only rarely, and almost never print examples of it, the Taranaki Herald and its colleagues are full of readers' compositions. Sonnets, odes, addresses and expostulations - they spring forth, if not on every page, then certainly in every issue. This was particularly true in times of war, when feelings ran high and frequently found their expression in literary form. Almost all these compositions are bad, needless to say - colonial New Zealand, alas, was no nursery of the Muses. The relative abundance of these compositions underlines, however, how differently literature was viewed a century and a half ago in this country: as something urgent, relevant and important.

The most fascinating piece I came across is a kind of dramatic monologue. Entitled "The Death of Taiporutu", it was composed by a certain A. King, aidede-camp to Major-General Pratt, Major-General Gold and Major-General Cameron, who had been conducting the campaign against Taranaki Maori and their allies. The piece purports to be the poroaki (farewell address) of a notable Ngatihaua chief, Wetini Taiporutu, a cousin of Tarapipipi's, who had been severely wounded at the battle of Mahoetahi, fought a short time before. Poroaki were traditionally spoken by a dying chief to the assembled tribe, but this one is addressed to the European readers of the newspaper. As an example of cross-cultural borrowing (or mutilation) it is worth quoting in full:

Pakeha! Pakeha! Pakeha! Listen, listen to Taiporutu, chief of Ngatihaua, tribe of Waikato. When the big canoe of the white man crossed the great salt lake and came to New Zealand, Taiporutu was then a little boy. Many, many moons have passed over the snows of Tongariro, and the shadow of the sun has for many days looked upon the graves of my forefathers since that time. But the tomahawk of the Waikato was thirsty, and his spear lay idle, when Korohena kissed the son of the warrior chief of 
Waikato and bade him lift the spear of his father and hurl the tomahawk at the scalp of the pale-skinned chiefs. The summer winds had breathed upon the brow of Taiporutu; he then became a man. But the dark spirit that bade him harm the Pakeha lay hid. The Missionary told him of another, better and far-off land, where the flowers grow not old or ever die; where the good Pakeha and the good Maori live together in peace. Then came the blanket, the tobacco, and all the good things. The Maori and the Pakeha then sat in the pa together in peace, while the birds sang the sun into the West. The tomahawk and the gun lay buried. But Taipo, the dark spirit, awoke, spread his wings over Taranaki, and the korero was bathed in blood.

The pas of Ngatiawa and Puketapu paid utu for the homes the Maori had burned of the white man, but no utu for the blood of the white man had been taken; the blood of the Ngatiawa and Puketapu was not rich enough, for the blood of its tribe vile slavery left them no chiefs, for the Waikato had bound them with an iron belt. Wiremu Kingi cried to the warriors of Waikato to redeem the whenua the Maori had sold to the Pakeha; so the Waikatos left the pas of their forefathers to fight the battles of the Maori. Mahoetahi has broken the standard of the Maori King, and the boy of Potatau weeps the loud wail of the tangi over lost places in the pas of the Waikato warriors. Pakeha! Hear me; listen to the last words of Taiporutu! The best blood of Waikato flows as utu for your murdered men, not mine alone, for Hemi, my noble boy, now lies bleeding at my feet. The young pine of Waikato is struck down and blackened by the rifle smoke of the pale-faced warriors ere the war-feathers had kissed the brow of the young chief of Ngatihaua; there is darkness in the tribe, and Waikato is in a mist for the loss of her chiefs. I see the Rangatira, the great Rangatira warrior; his brow is troubled, and his heart is full. Look upon my bleeding boy, and let not your common warriors close his eyes, for he is the son of a great chief. Ah, Wi Kingi! The Waikato has been stung - the Ngatiawa is false! He has sung the loud song of the battle; he has danced the war dance with the Puketapu; but he slept in the pas of Huirangi while the warriors of the pakeha struck down the pride of Waikato at Mahoetahi! Ha! I now see the slave has sold his master! Hear, Ngatiawa, hear! As warrior on no battle field shall thy coward carcase lie. Wear for ever the blanket of thy wahine, slave as thou art! Oh, the winds kiss the wounds of Taiporutu, but in the pa of the chief of Ngatihaua will soon be heard the tangi - the piercing wail of Katrina for her poor boy, her heartbroken cry for Taiporutu! Soft, soft, Pakeha! The dark spirit has fled. The Maori sees coming from the mountain snows of Egmont another spirit clothed in white. Hear the korero of the good spirit! The tomahawk of Taiporutu is broken, his canoe is stranded, and his pa is empty. The Pakeha, the Rangatira is 
good, is very good; the Maori King a dream. Let the Pakeha who has given the Maori everything; let the Pakeha who has sung to the Maori an angel's song - let, I say, the white man and the dark skin dwell together in peace. Good, good, these are the last words of Taiporutu - my boy - my poor boy - no King - Pakeha - Pakeha - forgive - forgive - for - dies. (Taranaki Herald 15/1/1861.)

This is, I think you will agree, a remarkable piece of writing, not because it is "good" or "true" but because it so cheerfully - indeed shamelessly transgresses every cultural standard, annexing a venerable Maori oratorical form for its own unabashedly Victorian and propagandist purposes.

There is, for instance, plenty of melodramatic sentiment (the dying chief talks of his wife Katrina making a "piercing wail" for her "poor boy"). There is also a yoking together of entirely separate indigenous traditions, in this case the Amerindian and the Polynesian (notice the way the piece moves from the Hiawatha-style "Red Indian" imagery ("great salt lake", "many, many moons") to references to genuine Maori practices such as tangi (mourning) and utu (payment, revenge)). Such a combination of different indigenous cultures, it has to be said, is typical of the period - in at least one near-contemporary New Zealand novel, George Wilson's Ena (1874), for example, Maori are described as "scalping" their victims and as wearing "feather headdresses" (Ena 89). This suggests that the writer, like many Victorian colonial writers, had a kind of vague, composite indigene in his mind when he came to write this monologue, a composite that owed more to the novels of Fenimore Cooper and the poetry of Longfellow than to any real anthropological observation.

These Victorianisms, as I mentioned, are coupled with a determinedly proEuropean, propagandist viewpoint, according to which Maori are portrayed as weak and misguided, dupes of "Taipo, the dark spirit" (a Satan figure) and betrayed by their own race (specifically, Ati Awa). The new settler culture, by contrast, is described in terms of peace, light and heaven - the Pakeha (European) has, Taiporutu says, "sung to the Maori an angel's song". The message, in fact, could not be clearer: Maori have gained everything from their contact with Europeans and must stop fighting with them. Given the date of composition - January 1861, when the Taranaki War was dragging on unresolved - this sentiment is unsurprising, but it is interesting to see it expressed as crudely as it is here.

Despite its obviously dramatic nature "The Death of Taiporutu" was never performed. Possibly, indeed, it was never intended to be staged, being a purely literary composition designed for silent perusal by the readers of the Taranaki Herald. In any case, if the writer, A. King, had ambitions to perform 
in public, these were crushed when, a few months later, he gave a talk in Nelson in which he praised the conduct of the Taranaki campaign, describing it as an exemplary success. His audience, the Nelson Examiner reported acidly, were having none of this - booing was heard, and the chairman thought it wise not to ask for a vote of thanks for poor lieutenant King (Nelson Examiner 25/9/1861).

\section{Works Cited}

Nelson Examiner, 25/9/1861.

Taranaki Herald, 15/1/1861.

Wilson, George. Ena; or the Ancient Maori. Smith, Elder and Co., 1874. 